\title{
PSYCHE.
}

\section{ON COLEOPTERA FOUND WITH ANTS. (FOURTH PAPER,)}

BY H. F. WICKHAM, IOWA CITY, IOWA.

The following notes are intended to be supplementary to those which I have contributed to earlier numbers of Psyche. While fragmentary, they will add something to the knowledge of our native Myrmecophiles.

A reëxamination in May, 1896 , of the nest of Formica obscuripes (at Iowa City) from which the specimens of Platymedon laticolle had been taken in preceding years, showed that for some cause the ants had deserted it and moved to another locality a few feet distant. On digging into this new nest it was seen that the Platymedon had followed its host since more than twenty specimens were obtained. Anthicus melancholicus had also accompanied the ants to their new home, but I found them more abundant in the old deserted mound than in the fresh one. Early in 1897 I again went out to visit this colony and found it so weak that I judged it better not to disturb it, particularly as no other colony of this species has ever been noticed in this part of Iowa. Lately Mr. A. W. Hanham sent me specimens of the same Platymedon, captured with $F$. obscuripes near Brandon, Manitoba; he took them by placing flat stones on the nest, when on his return a week later (April 23rd) the beetles were found beneath them. Some, he writes, got away before he could catch them - and indeed the little creature is very quick in its motions and makes the most of the opportunities for concealment afforded by the debris composing the mound. In the same nest Mr. Hanham took large numbers of the case-bearing larvae of Coscinoptera dominicana, April $\mathrm{s} 6$ th. The cases, he says, were nearly as numerous as the ants and were generally attached to the twigs of which the mound seemed to be chiefly composed. The first beetles were disclosed May $x 7^{\text {th }}$ and are of the densely pubescent type noticed by Dr. Horn as belonging more particularly to western specimens.

A species of Stilicus sent from Winnipeg by Mr. Hanham seems undoubtedly new and is described below. It is said to be found under stones in company with ants through the earlier part of the season, having been taken at various dates between April 22 nd and

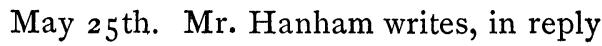
to a query, whether the insect should, 
properly speaking, be considered myrmecophilous - "I should say they are certainly a species living with ants. In the early season I find the railway lines, in some places, the best collecting ground. On both sides of the track are stones, under most of which are ants, representing one species and of much the same size and color as these beetles. There have always been ants with the beetles taken, but sometimes even large colonies of ants have furnished no specimens of the Stilicus, though as soon as I got to distinguish the beetles from the ants and to know where to look for them, I would usually get one or a pair, if not more, from each nest, sometimes as many as half a dozen. I have also taken it rarely, under stones, in September."

The evidence is such that we must conclude that the beetle is in some way connected with the ants, since it shows such preference for their company. While other species of Stilicus are found under stones in the spring, it has never been noticed that they are confined to the vicinity of ants' nests. I have therefore included the insect under consideration in our list of myrmecophiles and have drawn up the following description. The name is proposed in recognition of the careful labors of its discoverer among the insects of Manitoba.

S. hanhami n. sp. Much stouter than $S$. dentatus, blackish clothed with yellowish or golden recumbent pubescence. Antennae, mouth-parts, prothorax and legs reddish brown, elytra of about the same color as the prothorax but bearing a large suturo-basal picescent cloud. Abdomen above black, margin paler, tip still lighter in color. Body beneath piceous except the prothorax which is reddish brown and the median and apical tracts of the abdomen which are pale. Head large, subquadrate, sides behind the eyes feebly arcuate, hind angles rounded, base deeply sinuate; above closely punctured, each puncture with a golden hair, forming so close a covering as to obscure the sculpture, under side with a distinct smooth impressed median line, the punctuation otherwise resembling that of the dorsal aspect. Antennae stout, first joint longest, second to fifth longer than wide, sixth to tenth nearly globular, eleventh longer than the tenth and pointed at tip. Teeth of labrum small, slender and prominent. Prothorax broadest in front of middle, sides broadly rounded and narrowing from this point to base which is truncate and with a distinct basal marginal line, hind angles not defined; anteriorly the prothorax narrows rapidly to apex, the sides straight or very slightly sinuate. Upper surface convex, rather shining, the punctuation finer than that of the head, not dense, each puncture with a golden hair. Lateral margin with two long bristles and a shorter one near each front angle. Median line distinct. Prosternum carinate, sides punctured and apparently finely transversely rugose. Elytra broader than the prothorax, punctures fine with hairs like those already described. Abdomen with broad distinct side margin, finely moderately closely punctate and hairy, sides bristly, the bristles on the last three (visible) segments much longer than the others. Under side punctured and pubescent, the golden hairs mixed with numerous longer black ones. Legs punctured and pubescent. Length (total) $4 \mathrm{~mm}$.

A specimen was sent to Captain Casey who writes that it is near opaculus Lec., but much stouter with a larger 
head more deeply sinuate at base. The plate will give an idea of the more salient features, the figures being drawn by Mr. P. C. Myers and the author. Fig. I is an outline of the type specimen, $a$ is the mandible, $b$ the maxilla, $c$ the labium (in which the palpus is shown on one side only, the paraglossa on the other), $\mathrm{d}$ the antenna and e the hind tarsus. Figs. $2 \mathrm{a}, 2 \mathrm{~b}$, and $2 \mathrm{~d}$ represent hitherto unfigured details of Platymedon laticolle which are of interest in this connection. It will be noticed that the terminal antennal joint is sinuate or somewhat ogival at tip. The mandibles are stouter than in Stilicus hanhami. The fourth joint of the maxillary palpi is extremely minute and scarcely visible except by careful preparation. The four teeth of the labrum (fig. $2 f$ ) are unequal, the outer being much smaller than the inner.

A nest of Lasius niger was examined at Iowa City on May 5 th. The gallerie were in and under old logs. Running with the ants were seen two individuals of Myrmobiota crassicornis Casey. They are difficult of detection owing to their habit of keeping close to their hosts and mingling with the moving mass. My other specimens of this beetle were taken in August so that this record points to the probability of hibernation or of a double brood.

During a six weeks' trip to Colorado, some effort was made to add to the records of myrmecophiles, but the season was so far advanced that but little success was achieved. At Colorado Springs two species were taken, which, with their hosts, have been identified by Prof. Jerome Schmitt. These were Batrisus frontalis which was found in the runways of Lasius claviger beneath a log; and Batrisus globosus which occurred in a colony of Camponotus herculeanus.

\section{A STUDY OF THE CATERPILLARS OF NORTH AMERICAN SWALLOWTAIL BUTTERFLIES. - II.}

\section{BY SAMUEL H. SCUDDER, CAMBRIDGE, MASS.}

From these statements we see that there is a somewhat general uniformity of type in the earliest stage of larval life among the Papilionini, while there is an extraordinary diversity in the same caterpillars when full grown. Some of them alter very much less than others, some assume the mature aspect by slow degrees, and others at a start and at very different periods of life.
Thus maturity may be said to be assumed at the second stage by Laertias and Iphiclides, at the fourth by Heraclides and Papilio, in the course of the fourth stage by Jasoniades, and not until the final stage by Euphoeades. This assumption of maturity consists in several distinct features which in general are correllated: the form of the body, the broad features of the coloring 

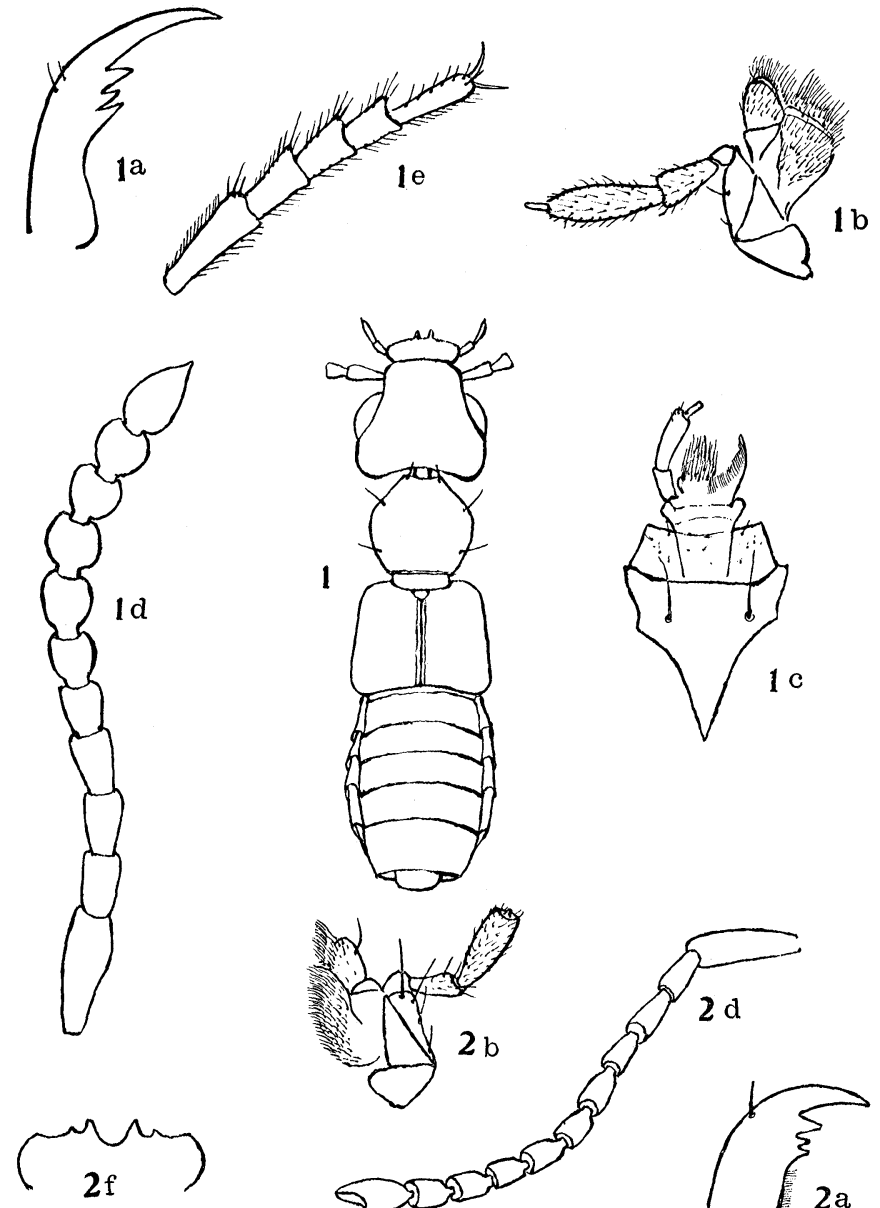

$2 \mathrm{~d}$

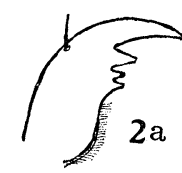

WICKHAM-MYRMECOPHILOUS COLEOPTERA. 

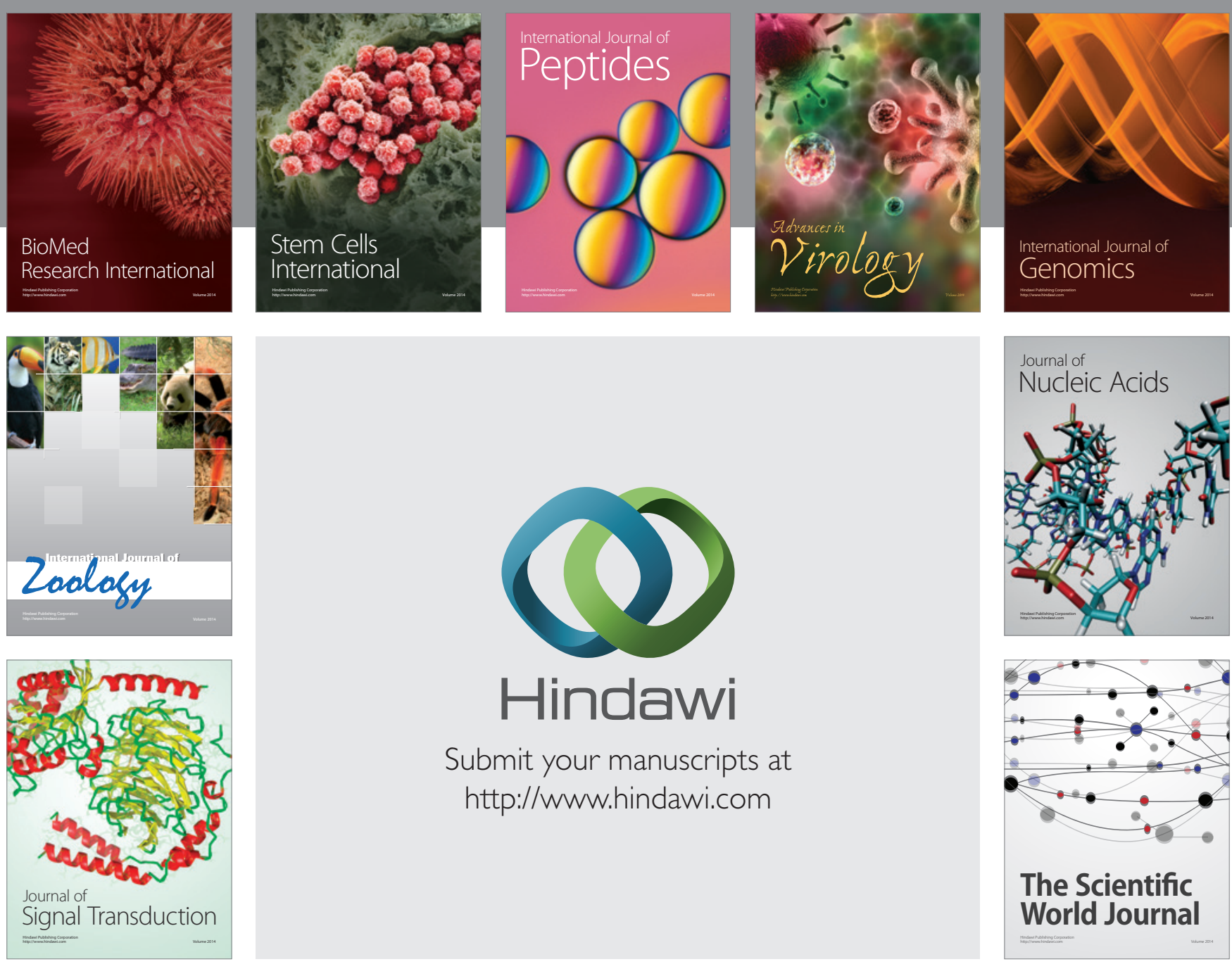

Submit your manuscripts at

http://www.hindawi.com
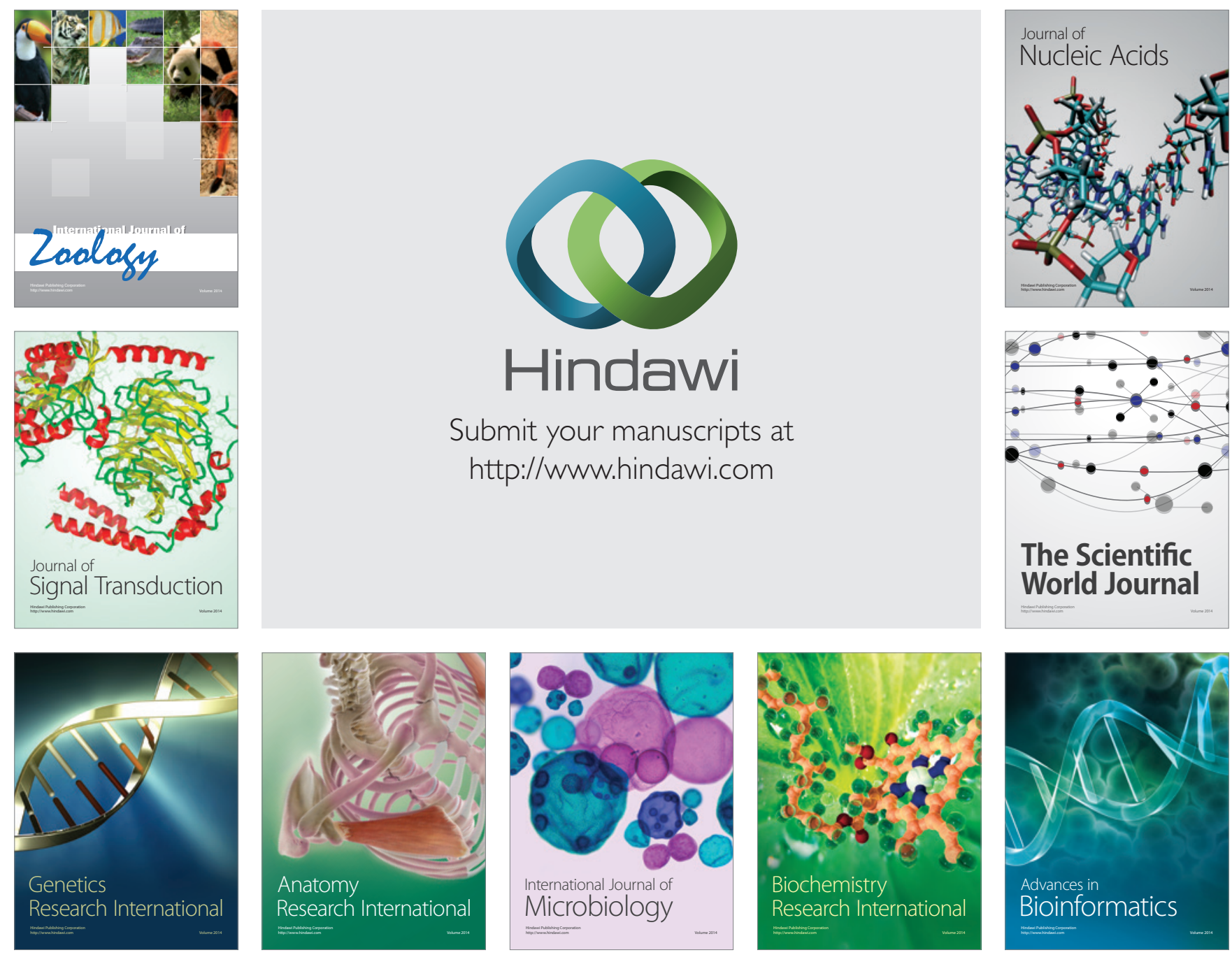

The Scientific World Journal
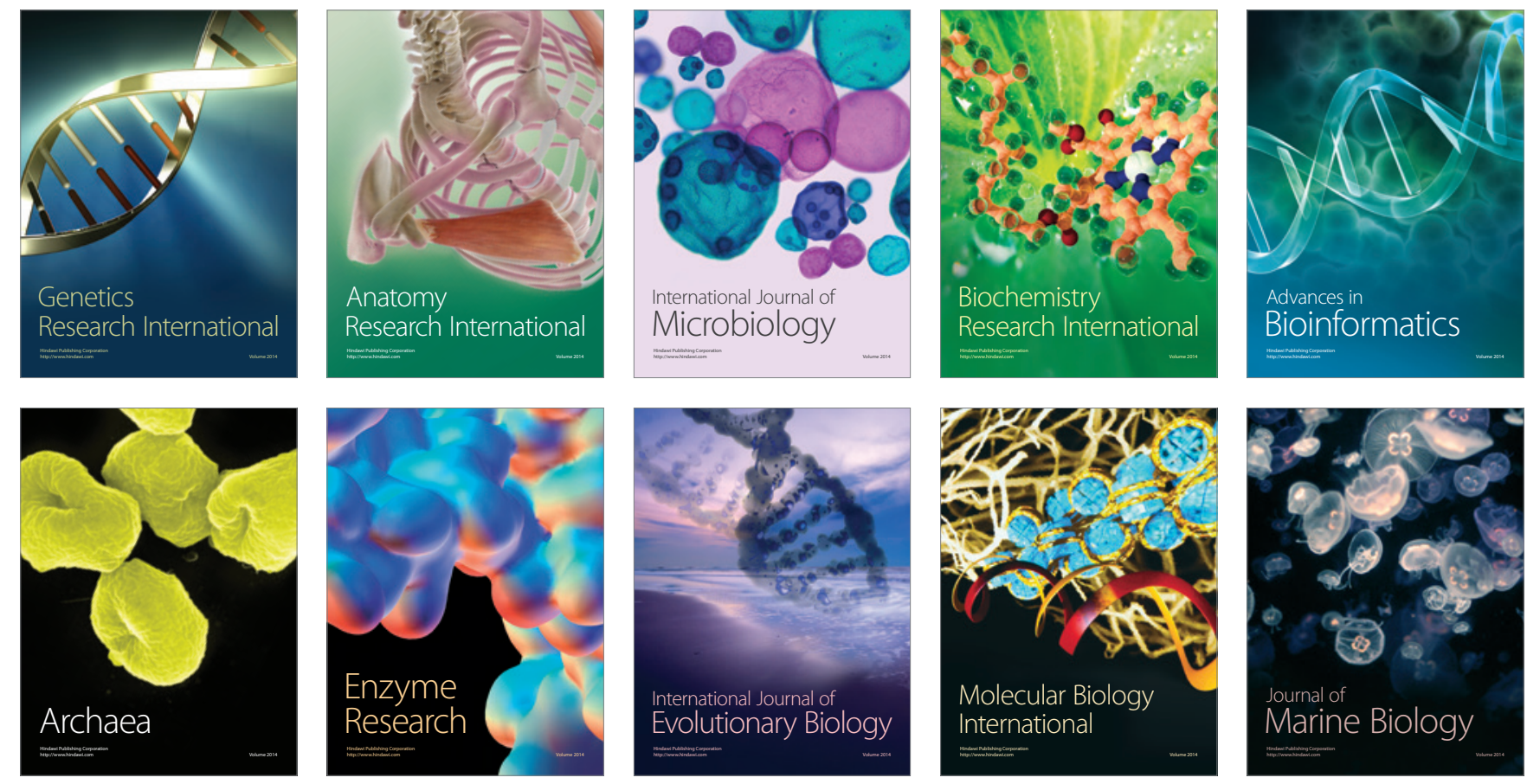